\title{
English Education in Italy: Perceptions of Teachers and Professors of English
}

\author{
Farahnaz Faez (University of Western Ontario)
}

\begin{abstract}
This paper examines the growing impact of English in Italy and in the Italian education system. The analysis focuses on issues of educational policy and practice and addresses discrepancies that exist across these areas with regards to English proficiency and use among Italians. The first part of the paper examines English dominance in non-Anglo countries, the education system in Italy and foreign language policy initiatives of the European Union that impact language policy and practice in Italy. The second part of the paper reports on findings of a survey completed by high school teachers and professors of English as well as interview data on their perceptions on the role of English in the Italian education system and the society at large. While this study focuses on the situation in Italy, the results have resonance for other contexts in Europe and beyond.
\end{abstract}

\begin{abstract}
Résumé
Cet article examine l'impact croissant de l'Anglais en Italie et dans le système éducatif italien. L'analyse se concentre sur les questions de politiques et pratiques éducatives et aborde les divergences existant à travers ces domaines, par rapport à la maîtrise de l'Anglais chez les Italiens et leur usage de la langue. La première partie de cet article examine la domination de l'Anglais dans les pays non anglophones, le système éducatif en Italie et les initiatives en manière de politique des langues étrangères de l'Union Européenne qui affectent les politiques et pratiques des langues en Italie. La seconde partie de ce document rapporte les résultats d'enquêtes complétées par des enseignants d'école secondaire et par des professeurs d'Anglais, de même que les données d'entretiens sur leurs perceptions du rôle de l'Anglais dans le système éducatif italien et dans la société en général. Bien que cette étude mette l'accent sur la situation en Italie, les résultats s'étendent aussi à d'autres contextes en Europe, et ailleurs.
\end{abstract}

\section{INTRODUCTION}

The status of English as the fastest growing language in the world is uncontested. Given today's global economy, it is not surprising that $25 \%$ of the world's population uses English for some purposes (Kachru \& Smith, 2008) and this percentage is on the rise. English has gained the status of the language of "global communication" (de Swann, 2001, p.6) and the "language of the world market" or "commercial lingua franca" (Brutt-Griffler, 2002, p. 49). Countries which have not had a previous Anglo affiliation (e.g., Italy) are now facing the growing hegemony of the English language. These countries are facing a dilemma: preserve their own language, culture and history and attempt not to participate in the growing impact of English or become involved in the spread of English as the lingua franca of the economic world.

This article examines the growing impact of English in Italy and the Italian education system. The first part of the paper examines the dominance of English worldwide as well as the European Union's foreign language policy 
initiatives that impact Italy's education system and language practices. The second part of the paper focuses on findings of a survey completed by twenty nine high school teachers and professors of English which investigated their perceptions on the role of English in the Italian education system and the society at large. Additional data was gathered from interviews with six high school teachers and professors of English. The analysis of the data revealed the following three themes that provide insights into the significance of learning English in a non-Anglo European country: (a) the need and motivation for learning English, (b) the role of the English language in the Italian public school system and (c) preferences for British and/or American English. In light of the role of English as the lingua franca in Europe and the language of internationalization and globalization, the analysis focuses on issues of educational policy and practice that generate discrepancies between English proficiency and English dominance within the context of Italy. Finally, the paper addresses some of the educational and political issues involved in the spread of English in Italy.

\section{ENGLISH DOMINANCE IN NON-ANGLO CONTEXTS}

Over the past two decades there has been a growing interest in examining the role of English in countries in which English has traditionally functioned as a foreign language ${ }^{1}$. There is no shortage of studies that have investigated the role and impact of English within national and supranational levels worldwide. The role of English has been examined, for example, in Asian countries such as China, south Korea and Japan (e.g., Bolton, 2003; Kubota, 1998; Matsuda, 2003; Park, 2009; Sakai \& D'Angelo, 2005; Tanaka \& Tanaka, 1995), in former Soviet Republics (e.g., Proshina, 2005), in Latin America (e.g., Berns \& Friedrich, 2003; Nino-Murcia, 2003; Zappa Hollman, 2007), and in Europe (e.g., Erling, 2007; Hilgendorf, 2005, 2007; Jenkins, 2009; Modiano, 2009; Nikula, 2007; Pulcini, 1994, 1997). Other scholars have examined the supra national and global impact of English such as linguistic dimensions of globalization (Brutt-Griffler, 2002; de Swaan, 2001; Majhanovich, 2009; Pennycook, 2007; Phillipson, 2003, 2009; Seidlhofer, 2004), practical uses of English in a globalized economy (de Swaan, 2001) and the spread of English as a form of linguistic imperialism and post or neo-colonialism (Pennycook, 2002; Phillipson, 2003, 2009).

Within the European context, scholars have examined the influence of English in the European Union (Labrie \& Quell, 1997) as well as in specific countries such as Belgium (Goethals, 1997), Finland (Nikula, 2007), France

\footnotetext{
${ }^{1}$ The term foreign language is used to refer to a language that is not the language of communication within a specific context.
} 
(Truchot, 1997), Germany (Thümer, 1997), and Italy (Pulcini, 1997), to name a few. Recent studies within the European context have also explored the specific domains where English prevails such as education in Germany (Erling, 2007; Hilgendorf, 2005, 2007) and Finland (Nikula, 2007) as well as advertising in France (Martin, 2006). Despite the wealth of studies in English dominance internationally and within Europe, few studies have looked at the context of Italy (see however, Pulcini, 1994, 1997, 2002, 2008). Pulcini has looked at Americanization (1997) and Anglicism (2008) of the Italian society and Italian language. Pulcini (1997) reported that while the first half of the $20^{\text {th }}$ century revealed a sense of "hostility" towards English and Americanization, the second half of the century showed signs of "accommodation" and "acceptance". This study addresses a gap in research examining the role of English in the Italian context in part by examining the role and impact of English and English education from the perspective of high school English teachers and tertiary level instructors within a midsized city in Italy.

\section{THE EDUCATION SYSTEM IN ITALY}

In order to examine the role of English in Italy, a brief overview of the Italian Education system is necessary. Administration of the Italian education system is centralized. Even though there have been efforts towards decentralization since the late 70 s to regional and provincial units, not much progress has been made in this direction. There is a central general administration of elementary and secondary education called Directorates that deals with primary as well as lower and upper level secondary schooling. These directors make decisions regarding curriculum development and implementation, teacher recruitment, funding and other school matters and forward their recommendations to the Minister of Public Instruction (European Commission, 2010a).

Public education in Italy is free and mandatory from 6-15/16 years of age (European Commission, 2010a). Children 3 to 6 years of age have the option of attending preschool or kindergarten (scuola materna) for three years. Students start primary school (scuola elementare) at the age of 6 and the length of primary school is five years. The educational curriculum is uniform at this level. Students then begin lower secondary school or middle school (scuola media) at the age of 11 which consists of three years of study and involves an exam at the end of the third year. High school or secondary school (scuola superiore) is generally five years except for the vocational secondary school (istituto professionale) that might offer a diploma after three years. There are several types of secondary schools differentiated by activities and subject. The main distinction is between technical (istituto tecnico), scientific (liceo scientifico), classical (liceo 
classico), and foreign languages (liceo linguistico). The organization for economic co-operation and development (OECD, 2006) ranks the Italian secondary education system as the $36^{\text {th }}$ in the world. This is significantly below the OECD average for the education systems of 57 countries that were compared. This organization also observes a gap between the results in schools in Northern Italy compared to Southern Italy. Schools in the northern region of the country perform significantly better than the national average and schools in the southern area.

Universities, and a wide range of academies and institutes, provide higher education both in the artistic sector and in professional areas such as technology, fashion and industry (Euro Education, 2011). Students attend universities after the completion of thirteen years of schooling and obtaining the secondary school leaving qualification (Diploma di Superamento dell'Esame di Stato conclusive dei corsi di istruzione Secondaria Superiore), which is awarded by successfully passing the relevant state examinations. Following the Bologna Declaration $^{2}$ in 1999, the Italian university system shifted from a traditional 5year degree (laurea) to a new system that divides the degree into two stages: the laurea triennale which is a three-year degree program equivalent to the Canadian Bachelor's degree followed by a two-year laurea specialistica which is equivalent to a master's degree. The third cycle of tertiary education is a 3 or 4 year doctorate program (dottorato di ricerca). Universities operate autonomously within the laws set by the federal government. Students who pass the state exam at the end of upper secondary school have access to higher education (both university and non-university). Admission to various degree programs are subject to specific requirements and may or may not include foreign language proficiency requirements.

\section{ENGLISH IN THE EUROPEAN UNION}

In 2002, at the European Council meeting in Barcelona, the European member states, which included 15 countries at that time, agreed that, in addition to individuals' mother tongue, at least two languages should be taught from a very early age (European Commission, 2008). The European Union (EU) was enlarged in 2007 to include 27 member states and 23 official languages. The union then devised a multilingualism policy ${ }^{3}$ whose goals were to: (a) raise understanding of the EU's linguistic diversity, and (b) to provide all citizens

\footnotetext{
${ }^{2}$ In 1999 the Ministers of Education from 29 European countries gathered at the University of Bologna in the Italian city of Bologna to harmonize the academic degree standards throughout Europe. This agreement is named after the place it was proposed.

${ }^{3}$ Multilingualism: an asset for Europe and a shared commitment (COM) 2008566 final
} 
opportunities to learn two languages in addition to their mother tongue (European Commission, 2008). While the official policy is vague in understanding which two languages individuals should learn, there is tacit understanding that the first language is English (Erling \& Hilgendorf, 2006; Hilgendorf, 2005). Up until now, the EU has not adopted an explicit language policy addressing language use in Europe or the level of proficiency required, yet it is implicitly understood that English should be the language of communication. English has become the default language of the EU member states (Erling \& Hilgendorf, 2006; Phillipson, 2006, 2008; Wright, 2004) even though there is widespread objection and fear that national languages are at risk (e.g., Ehlich, 2004; Phillipson, 2006; Pennycook, 2002).

A number of initiatives by the EU have further enhanced the use and role of English in Europe. The objectives of the Bologna Declaration in 1999 (European Commission Higher Education and Training, 1999) were to promote greater compatibility in higher educational institutions across Europe in order to facilitate academic mobility for students, researchers and educators. While there is no reference to language policy requirements in the Bologna Declaration, it has led to the increasing need for individuals across Europe to know, use and learn English (Erling \& Hilgendorf, 2006; Phillipson, 2003). The popular exchange program in Europe entitled The European Action Scheme for the Mobility of University Students (Erasmus) allows students to study for the period of six months up to one year in a university at another EU country. A new credit recognition process has been established so that courses completed at other EU higher educational institutions are recognized by partner institutions. One of the objectives of this program, among others, is to promote language learning and it is undoubtedly promoting the learning and use of English in Europe (Erling \& Hilgendorf, 2006). In virtually all EU countries for which data is available, English is the most widely taught foreign language with the exception of Belgium and Luxembourg. Overall, 90\% of EU members learn English; 40\% German and 30\% French (European Commission, 2008).

\section{FOREIGN LANGUAGE EDUCATION IN ITALY}

The European Commission (2008) reports findings based on Eurydice and Eurostat sources that are useful in understanding trends in teaching of foreign languages in Europe and in Italy. Following the Barcelona European Council in June 2002, in which the agreed goal of the European member states was that at least two foreign languages should be taught from an early age, Italy introduced reforms related to the teaching of foreign languages. Italian is the official state language in Italy while other languages (e.g., German, French, Greek, Catalan, 
Slovene) are recognized as regional and/or minority languages with official status. Twelve percent of students in secondary schools speak a language at home that is not the language of instruction at school (European Commission, 2008). Following the recommendations issued at the European level, since 2006 it has been compulsory for all students to learn two foreign languages beginning at the primary school level. English is mandatory as soon as students start primary school at the age of 6. In fact, Italy is among those countries (after Spain) in which students are taught English earliest during their education. It is common to find students studying English in nursery school but this is not compulsory. The education reform of 1984 (European Commission, 2008) resulted in a shift in the age in which students are initially taught a foreign language (i.e., age 11 in 1984, age 8 in 1994, age 7 in 2003 and age 6 in 2007). In 2006, 99.9\% of the student population in primary school learned one or two foreign languages in primary school (98.1\% one language; $1.9 \%$ two languages). All students have to learn a second foreign language in lower secondary (ages 11-14). School autonomy in Italy results in relatively less emphasis on foreign languages in secondary schools compared to other European member states. In primary schools, English is often taught by general teachers who do not receive initial training to teach foreign languages but participate in in-service professional development activities. At the secondary level, qualified language teachers teach foreign languages. Initial teacher education programs for foreign language teachers last six years which is one of the longest programs among EU member states. In such programs theoretical courses on the teaching of foreign languages and in-school foreign language teaching placements are offered (European Commission, 2008).

The goals of the European Day of Languages, a yearly event initiated by the Council of Europe in 2001 are to indicate to the public the significance of language learning, to enhance the rich cultural and linguistic diversity of Europe and to encourage lifelong language learning of EU member states in and out of school (Europa, 2009). In 2007, 60\% of the students in upper secondary schools in the EU studied two or more foreign languages and one third studied only one foreign language (Europa, 2009). Among the 29 member states of the EU, Italy ranked the second highest country for the proportion of students studying one foreign language (English) in upper secondary school (74\%) after Greece (92\% in 2006). This percentage does not include the number of students who studied two or more foreign languages $(24.6 \%)$. The percentage of the students in the upper secondary school who studied English in Italy increased from $78.3 \%$ to 95.3\% from 1998-2007 (European Commission, 2010b).

The amount of time spent on foreign language teaching in each academic year is 80 hours in primary school which has remained unchanged from the 2002 
to 2007. This time has increased considerably at the lower secondary level from 70 hours to 165 hours per academic year. With a total of 891 hours of language education during primary school and lower secondary school, Italy is one of the countries with a high total hour of instruction devoted to language education. The minimum amount of time allocated to foreign languages in the secondary level is $17.2 \%$ of total teaching time which again is high compared to other EU member states (European Commission, 2008).

According to a survey of peoples' knowledge of languages in 29 countries (European Commission, 2006) English was the most widely used foreign language in 19 of those countries. Of the individuals surveyed, 38\% were proficient in English compared with only 14\% in French or German. Sweden and the Netherlands ranked among the highest in terms of levels of individuals' English proficiency with $89 \%$ and $87 \%$ respectively. 59\% of Italians admit to not know any other language besides their mother tongue.

Educational authorities and institutions in the EU recommend the use of the Common European Framework of Reference for Languages: Learning, Teaching and Assessment (CEFR) for understanding levels of language proficiency and as an assessment tool. The CEFR was developed by the council of Europe in 2001, in order to provide "a common basis for the elaboration of language syllabuses, curriculum guidelines, examinations, textbooks, etc. across Europe" (Council of Europe, 2001, p.1). The new curriculum guidelines that came into effect in 2007 in Italy recommend the use of the Common European Framework of Reference for Languages (CEFR) (Council of Europe, 2001) for assessment. The goal is for students at the end of the secondary level to be at the B2 level.

\section{THE STUDY}

\section{Participants and Sources of Data}

Data for this study were gathered through an online survey and interviews with high school teachers and university professors of English. The online survey and interviews were conducted in English. Participants were from a midsized industrial city in Northern Italy. Twenty-nine English educators participated in an online questionnaire that probed into their attitudes and perceptions about the role of English and English Education in Italy. Three of the participants spoke English as their first language and the rest were speakers of the Italian language. There were three male and twenty six female participants. Sixteen respondents were high school teachers and thirteen were university professors. Six high school teachers and university instructors of English were also interviewed to provide a deeper understanding of the issues discussed in the online 
questionnaires. Participants were asked to rank their responses on a four point likert scale: strongly disagree-disagree-agree-strongly agree.

\section{Findings}

This paper focuses on the three major themes that emerged out of the survey and interview data: (a) the need and motivations for learning English, (b) the role of the English language in the Italian public school system, and (c) preferences for British and/or American English.

\section{Perceptions of the need and motivation for learning English}

All participants agreed or strongly agreed that Italian citizens need to learn English in order to participate in the global economy. This is not surprising given the general trend towards globalization and the role of English as a lingua franca. However, only $79.3 \%$ of respondents believed that Italian citizens were motivated to learn English. The level of motivation varied among the participants for primary, secondary and post-secondary education. While $75 \%$ of the participating educators believed that students at the primary level were motivated to learn English, this percentage dropped at the secondary level to $67.8 \%$ and increased to almost $90 \%$ at the post secondary level. The teachers and professors interviewed felt that students were generally motivated to learn English as they are surrounded by English through the internet, exposure to music and movies as well as for their aspirations for future employment. Almost all of the respondents believed that knowledge of English language increases employment opportunities within Italy and that English proficiency increases such opportunity abroad (92.9\% and $96.4 \%$ respectively). Again, almost all of the respondents (96.3\%) indicated that English is required for youth and their participation in youth culture (e.g., media, music, movies, travel). In spite of the high reported levels of motivation only $6.8 \%$ of the respondents felt that Italians possessed acceptable levels of language proficiency compared with other European citizens. Ryan ${ }^{4}$, a British professor of English, who had resided in Italy for over ten years at the time of this study, elaborated on this discrepancy. In his view, Italian individuals' motivation to learn English was "superficial" rather than "deep" which he also perceived to be a positive attribute. He stated:

average Italians are motivated to learn English in order to travel, to enhance their employment opportunities and to understand movies and music. However, Italian citizens are generally not motivated at a "fundamental deeper" level because of two things: (a) they can be

\footnotetext{
${ }^{4}$ Pseudonyms have been used.
} 
quite successful without knowing English, and (b) there is a strong healthy Italian culture that Italians appreciate and enjoy.

Ryan used the prime minister of Italy as an example of a successful individual who did not know English very well. He therefore rationalized that Italians can be quite successful without high levels of English proficiency. He also stated, "You will be surprised how many politicians in Italy don't know in English". Furthermore, he believed that the "strong" Italian culture, for which Italian music was one example, contributed to individuals' lack of strong levels of motivation to learn English. He explained, "There is a strong culture here, you get plenty of what you need in life without English, and that is a good thing." Ryan's views on issues of motivation for learning English partly explains the perceived lower level of English proficiency of Italian citizens compared to other EU member states.

Another explanation provided to justify low levels of motivation was the fact that books, movies and other resources generally get translated into Italian thus contributing to a lower level of need and desire for knowing and learning English. Only $40.7 \%$ of the respondents agreed that there are opportunities to exposure to English outside of the school context. Lisa, a university professor, indicated that, "I've thought to myself, even if you don't know English, you're $\mathrm{OK}$, because things do get translated into Italian very quickly, you are not cut off from the rest of the world"

\section{The role of the English language in the Italian public school system}

All participants unanimously agreed or strongly agreed that English education in Italy is influenced by globalization but less than half (40.7\%) of the participants agreed that the goal for English education it to assist individuals to participate in the global economy. As for availability of English instruction in the public school system, $92.6 \%$ of the respondents indicated that English instruction is available to all students in the public school system and 59.3\% stated that English instruction is available to students at the post-secondary school level. Interestingly, only a quarter of respondents (25.9\%) agreed that public language education is effective and no one strongly agreed with this statement. Also only half $(51.8 \%)$ of the respondents agreed that teaching methods used for English instruction at the primary and secondary levels are effective. Almost all participants $(92.6 \%)$ agreed or strongly agreed that teaching methods need to be improved or further developed and three-quarters of them (77.8\%) agreed or strongly agreed that there are sufficient teaching resources such as textbooks and consultants in educational institutions for teaching English. These findings show that public English instruction is available at the primary and secondary levels 
and with the new foreign language policy reforms English instruction is available from a very early age (i.e., age 6) but educators in this study do not believe it is effective. Ryan commented on the new reform policy that took effect in 2006 making the learning of two foreign languages mandatory in the public education system:

that policy took effect two years ago, two not one foreign language, and a colleague of mine here was furious about it, well she thought it was ridiculous, that they are not learning English very well, now they learn English even worse plus another language pretty badly too; which I think was exaggerating; but interesting, is what her comment was; she is an English teacher, a literature teacher.

As the survey data and interviews show, overall, teachers were not satisfied with English instruction in the country. Teachers commented that in Italy, "bureaucracy" consumes a lot of their valuable time. Teachers have to spend a lot of time filling out unnecessary forms and they have to constantly "test" the students. Sima, an English high school teacher commented:

What I don't like is generally the Italian school system, for education which gives you, which makes you do a lot of other things, bureaucracy. Like filling in every kind of form, you have a lot of, for example of marking at home and you have to... ah... prove that you do this a lot of times. You are not free to choose when you want to do that; so in a way you are compel[led] to... for example to test them written and orally three times every three months so it becomes a sort of.... a structure... in which you do not feel free but, this is sort of what we call bureaucracy.

Teachers also commented that they lacked sufficient resources in the public school system and that English language teaching focused more on traditional ways of teaching. There was a lot of focus on grammar and accuracy and that a lot of teaching to the test takes places in the classrooms as students need to prepare for end of year national exams. Kathy, a high school teacher, commented, "teaching more like grammar-translation methods in which you only teach grammar and how to translate, but it doesn't really help people to communicate." (Kathy interview, December 2009)

\section{Preference for British or American English}

The questionnaire data as well as the interview data revealed no preference for British or American English. A third of participants (33.3\%) disagreed with the statement that Italians prefer British English over American English and 33.3\% agreed or strongly agreed with this statement (37\% of respondents did not respond to this survey item). As Lisa explained, "I studied in England so I'm 
fond of British English. But then, of course American comes across in films, in whatever, so I don't think I have a real preference and I think students should be exposed to both and learn both." Participants mentioned that students have more opportunities to learn and be exposed to British English simply because of Italy's proximity to the United Kingdom. Students have more opportunities to travel to the UK and be involved in exchange programs with the UK compared to the United States. For education purposes, teachers unanimously believed that students should be exposed to both varieties and should learn both varieties even though methods of doing so were not clear.

\section{DISCUSSION}

Within the European context it is clear the Bologna Declaration policy measures have had a huge impact on foreign language education policy in European contexts. English is the de facto first foreign language in primary and secondary education as well as higher education and is used as the medium of instruction in many degree programs at the university level (Erling \& Hilgendorf, 2006; Hilgendorf 2005). Hilgendorf (2010) reports that English is used in Germany among employees for communicating with inner, outer, and expanding circle countries and also for communicating with German colleagues.

In the case of Italy, reform policy initiatives have resulted in introducing English as early as grade one and increasing the number of hours devoted to language instruction in lower secondary school. This initiative can result in high school graduates receiving up to thirteen years of language instruction by the time they graduate from secondary school. In spite of these efforts, Italy is one of the countries that has the lowest levels of English proficiency in Europe. Pulcini (1997) noted that "Italians are renowned for being poor at foreign languages" ( $p$. 82) which she attributes to high levels of illiteracy until the middle of the $20^{\text {th }}$ century and to the use of various dialects of the Italian language which necessitates a strong emphasis on the national language rather than foreign languages. According to the survey reported by Europa (2009) 38.6\% of Italians did not speak any foreign language. Italy is one of the countries (after Spain) in which English is introduced earliest in the curriculum. The length of initial teacher education in Italy is also among the highest in Europe. The same report reveals that only 5\% of the Swedish population does not speak English. English is introduced later in the primary school curriculum in Sweden. Therefore, while policies and practices in Italy promote the learning and perhaps use of English, the proficiency of the citizens does not reflect such emphasis. It is important to note that the new policy initiatives in Italy are fairly recent and that more desirable outcomes might be underway with the new changes. 
It is also important to realize that policy initiatives can only be successful if the right infrastructure be in place. In the case of Italy, the teachers concerns about traditional ways of teaching through "grammar-translation" methods and "teaching to the test" should be considered and effective measures should be taken to support the development of communicative language ability in students. With regards to the CEFR, while the curriculum, textbooks and learning expectations seemed to be aligned with the proficiency levels outlined in the CEFR, the actual classroom practices of teachers, according to their self-reports, did not indicate the implementation of CEFR-informed pedagogies. What is more, there seems to be conflicting views about the role of English and English education in this country. On the one hand, English proficiency is regarded as important due to the potential employment and mobility opportunities it offers individuals. There is therefore extensive effort at the government and personal level for English education. On the other hand, there is fear and sometimes resistance in individuals that the hegemony of English might compromise individuals' sense of linguistic and cultural identity. As Ryan pointed out, the rich Italian culture and sense of community in Italy had resulted in individuals' possessing superficial and instrumental ${ }^{5}$ motivation to learn English rather than a deep integrative motivation.

The fact that, overall, respondents did not believe that Italians had a preference for American or British English and that educators believed students should be exposed to both varieties revealed that the pragmatic aspect of knowledge of English and English proficiency is emphasized in Italy. Therefore, it was clear that the notion of English as a lingua franca was dominant in that English was learned and used as a means for global communication rather than as an identity marker.

\section{CONCLUSION}

It is not appropriate to draw conclusions about the role of English in Italy based on a small sample of survey respondents and interviewees who were English language educators in only one city in Italy. However, the importance of conducting more in-depth analysis of language use in each setting becomes evident when each context provides unique perspectives into the hegemony of English. While the growing impact of English as a global language and the world lingua franca has definitely had its toll in Italy, as evident through the intensity of

\footnotetext{
${ }^{5}$ Instrumental versus integrative motivation is a distinction made by Gardner and Lambert (1972) to refer to factors involved in learning a second language. Instrumental motivation refers to the learning of a second language in order to achieve a future goal. Integrative motivation is "a complex of attitudinal, goal-directed and motivational variables" (Gardner, 2001, pp. 1-2).
} 
offering English in the Italian education system, at the same time, it seems that its penetration in the Italian society and culture has been moderate compared to other European contexts.

\section{References}

Berns, M., \& Friedrich, P. (Eds.). (2003). Special issue on English in South America: A different kind of difference. World Englishes, 22(2).

Bolton, K. (2003). Chinese Englishes. Cambridge, England: Cambridge University Press.

Brutt-Griffler, J. (2002). World English: A study of its development. Clevedon, England: Multilingual Matters.

Council of Europe. 2001. Common European Framework of References: Learning, teaching, assessment. Cambridge: Cambridge University Press.

De Swaan, A. (2001). Words of the world. Cambridge, England: Polity Press.

Ehlich, K. (2004). The future of German and other non-English languages of academic communication. In A. Gardt \& B. Huppauf (Eds.), Globalization and the Future of German (pp. 173-184). Berlin, Germany: Mouton de Gruyter.

Erling, E. J. (2007). Local identities, global connections: affinities to English among students at the Freie Universitat Berlin. World Englishes, 26(2), 111-130.

Erling, E. J., \& Hilgendorf, S. K. (2006). Language policies in the context of German higher education. Language Policy, 5(3), 267-292.

EuroEducation. (2011). Italy: Institution types \& credentials. Retrieved April, 2011 from http://www.euroeducation.net/prof/italco.htm

Europa. (2009). EuroStat news release: European day of languages. Retrieved July 23, 2011 from http://europa.eu/rapid/pressReleasesAction.do?reference=STAT/09/137\&type=HTML

European Commission. (2006). Eurobarometer: Europeans and their languages. Available at ec.europa.eu/public_opinion/archives/ebs/ebs_243_sum_en.pdf

European Commission. (2008). Key data on teaching languages at school in Europe: 2008 edition. Brussels, Belgium: Education, Audiovisual and Culture Executive Agency. Available at http://eacea.ec.europa.eu/education/eurydice/key_data_en.php

European Commission. (2010a). Organization of the education system in Italy. Available at http://eacea.ec.europa.eu/education/eurydice/documents/eurybase/eurybase full reports/IT EN.pdf

European Commission. (2010b, September). News release: European day of languages. In the EU, nearly $80 \%$ of children were studying a foreign language at primary school in 2008. Retrieved July 22, 2010 from

Http://epp.eurostat.ec.europa.eu/portal/page/portal/product_results/search_results?mo=containsall\& $\mathrm{ms}=$ language $+\&$ saa $=\& \mathrm{p} \_$action=SUBMIT $\& 1=\mathrm{us} \& \mathrm{co}=$ equal $\& \mathrm{ci}=, \& \mathrm{po}=$ equal $\& \mathrm{pi}=$

European Commission Higher Education and Training. (1999). The Bologna declaration. Available at http://ec.europa.eu/education/higher-education/doc1290_en.htm

Gardner, R. C. (2001). Integrative motivation and second language acquisition. In Z. Dornyei \& R. Schmidt (Eds.), Motivation and second language acquisition (pp. 1-20). Honolulu: The University of Hawaii Press.

Gardner, R. C., \& Lambert, W. (1972). Attitudes and motivation in second-language learning. Rowley, MA: Newbury.

Goethals, M. (1997). English in Flanders (Belgium). World Englishes, 16(1), 105-114.

Hilgendorf, S. K. (2005) "Brain Gain statt [instead of] Brain Drain": The role of English in German education. World Englishes, 24(1), 53-67.

Hilgendorf, S. K. (2007). English in Germany: Contact, spread and attitudes. World Englishes, 26(2), $131-148$.

Hilgendorf, S. K. (2010, May). Globalization and world Englishes. Paper presented at the Canadian Association of Applied Linguistics (CAAL/ACLA) conference, Montreal, QC.

Jenkins, J. (2009). English as a lingua franca: Interpretations and attitudes. World Englishes, 28(2), 200-207.

Kachru, Y., \& Smith, L. E. (2008). Cultures, contexts, and world Englishes. New York: Routledge.

Kubota, R. (1998). Ideologies of English in Japan. World Englishes, 17(3), 295-306.

Labrie, N., \& Quell, C. (1997). Your language, my language or English? The potential language choice in communication among nationals of the European Union. World Englishes, 16(1), 3-26. 
Majhanovich, S. (2009). English as tool of Neo-colonialism and globalization in Asian contexts. World Studies in Education, 10(1), 75-89.

Martin, E. (2006). Marketing identities through language: English and global imagery in French advertising. Basingstoke, UK: Palgrave Macmillan.

Matsuda, A. (2003). Incorporating world Englishes in teaching English as an international language. TESOL Quarterly, 37, 719-729.

Modiano, M. (2009). Inclusive/exclusive? English as a lingua franca in the European Union World Englishes, $28(2), 208-223$.

Nikula, T. (2007). Speaking English in Finish content-based classroom. World Englishes, 26(2), 206-223.

Nino-Murcia, M. (2003)."English is like the dollar": Hard currency ideology and the status of English in Peru. World Englishes, 22(2), 121-142.

Park, J. K. (2009). 'English fever' in South Korea: Its history and symptoms. English Today 97, 25(1). 50-57.

Pennycook, A. (2002). Language policy and docile bodies: Hong Kong and governmentatlity. In J. Tollefson (Ed.), Language policies in education: Critical issues. Mahwah, NJ: Lawrence Erlbaum.

Pennycook, A. (2007). Global Englishes and transcultural flows. New York: Routledge.

Phillipson, R. (2003). English-only Europe? Challenging language policy. London: Routledge.

Phillipson, R (2006). Figuring out the Englishisation of Europe. In C. Leung \& J. Jenkins (Eds), Reconfiguring Europe: The contribution of applied linguistics (pp.65-86). London: Equinox.

Phillipson, R. (2008). Lingua franca or lingua frankensteinia? English in European integration and globalization. World Englishes, 27(2), 250-267.

Phillipson, R. (2009). Linguistic imperialism continued. New York: Routledge.

Presidency conclusions: Barcelona European Council. (2002). Available at www.bolognaberlin2003.de/pdf/Pres_Concl_Barcelona.pdf

Proshina, Z. G. (2005) Russian Englishes. World Englishes, 24 [special issue].

Pulcini, V. (1994). The English language in Italy. English Today, 10(4), 49-52.

Pulcini, V. (1997). Attitudes to the spread of English in Italy. World Englishes, 16, 77-85.

Pulcini, V. (2002). Italian. In M. Görlach (Ed.), English in Europe (pp. 151-167). Oxford, UK: Oxford University Press.

Pulcini, V. (2008). Anglicisms in the 2006 olympic winter games, 2006. In R. Fischer \& H. Pulaczewska (Eds.), Anglicisms in Europe. Linguistic diversity in a global context (pp. 140-158). Newcastle Upon Tyne,

UK: Cambridge Scholars.

Sakai, S., \& D'Angelo, J. F. (2005). A vision for world Englishes in the expanding circle. World Englishes, 24(3), 323-327.

Seidlhofer, B. (2004). Research perspectives on teaching English as a lingua franca. Annual Review of Applied Linguistics, 24, 209-239.

Tanaka, S. O., \& Tanaka, H. (1995). A survey of Japanese sources on the use of English in Japan. World Englishes, 14(1), 117-135.

Thümer, U. (1997). EFL and EAP in the new lånder of Germany after 1989. World Englishes, 16(1), 87-93.

Truchot, (1997). The spread of English: From France to a more general perspective. World Englishes, 16, 6576.

Wright, S. (2004). Language policy and language planning: From nationalism to globalization. Basingstoke, UK: Palgrave.

Zappa Holman, S. (2007). EFL in Argentina's schools: Teachers' perspectives on policy changes and instruction. TESOL Quarterly, 41(3), 618-625.

Farahnaz Faez is an Assistant Professor in Applied Linguistics in the Faculty of Education at the University of Western Ontario. Her research interests are second language teaching and learning, pre-service and in-service ESL teacher education, internationally educated teachers, English language learners in K12 programs and World Englishes. She can be reached at ffaez@uwo.ca. 